University of South Florida

DIGITAL COMMONS

Digital Commons @ University of

@ UNIVERSITY OF SOUTH FLORIDA

South Florida

6-28-2016

\title{
Impact of Sludge Layer Geometry on the Hydraulic Performance of a Waste Stabilization Pond
}

Faissal Romaric Ouedraogo

University of South Florida, fouedraogo@usf.edu

Follow this and additional works at: https://digitalcommons.usf.edu/etd

Part of the Environmental Engineering Commons, and the Water Resource Management Commons

\section{Scholar Commons Citation}

Ouedraogo, Faissal Romaric, "Impact of Sludge Layer Geometry on the Hydraulic Performance of a Waste Stabilization Pond" (2016). USF Tampa Graduate Theses and Dissertations.

https://digitalcommons.usf.edu/etd/6344

This Thesis is brought to you for free and open access by the USF Graduate Theses and Dissertations at Digital Commons @ University of South Florida. It has been accepted for inclusion in USF Tampa Graduate Theses and Dissertations by an authorized administrator of Digital Commons @ University of South Florida. For more information, please contact digitalcommons@usf.edu. 
Impact of Sludge Layer Geometry on the Hydraulic Performance of a Waste Stabilization Pond

by

Faissal R. Ouedraogo

A thesis submitted in partial fulfillment

of the requirements for the degree of

Master of Science in Civil Engineering

Department of Civil and Environmental Engineering

College of Engineering

University of South Florida

Major Professor: Andres Tejada-Martinez, Ph.D.

Qiong Zhang, Ph.D.

James R. Mihelcic, Ph.D.

Date of Approval:

June 17, 2016

Keywords: Computational fluid dynamics, sanitation, sludge accumulation, pathogen, water reuse and reclamation

Copyright @ 9 2016, Faissal R. Ouedraogo 


\section{ACKNOWLEDGMENTS}

I would like to thank Dr. Andres Tejada-Martinez, my major professor, for giving me the opportunity when I was an undergraduate student to work on a research project that ignited my interest in Computational Fluids Dynamics (CFD); teaching the fundamentals of CFD and being available to provide invaluable guidance and advice anytime it was needed. I would also like to acknowledge Dr. Jie Zhang for his time and effort in teaching me about OpenFOAM code. Part of this study is based upon work supported by the National Science Foundation under Grant No. 1243510. 


\section{TABLE OF CONTENTS}

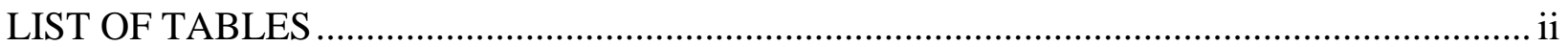

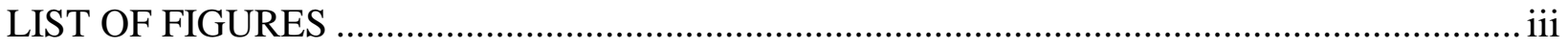

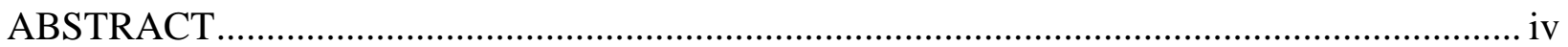

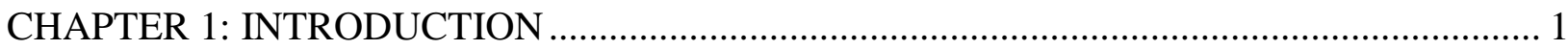

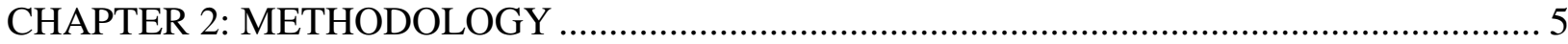

2.1 Waste Stabilization Pond Description ............................................................ 5

2.2 Modelling Approach .................................................................................. 5

2.3 Hydraulic Performance Evaluation Factors ..................................................... 7

2.4 Sludge Geometry Approach Cases.................................................................. 8

2.5 Pond Surface Water Level Approach and Cases ................................................. 11

2.6 Mesh and Numerical Tool.......................................................................... 11

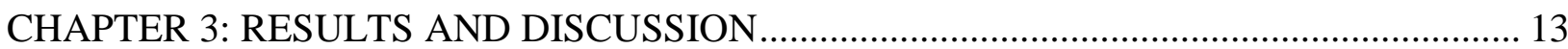

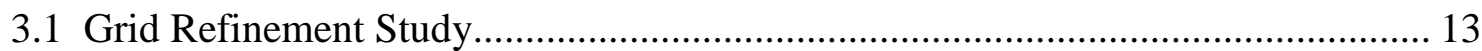

3.2 Impact of Sludge Layer Geometry on Hydraulic Performance............................ 14

3.3 Impact of Water Surface Level Change on Hydraulic Performance....................... 21

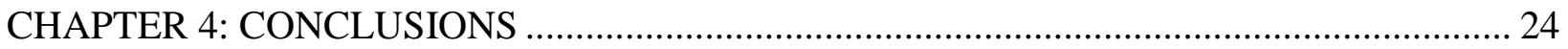

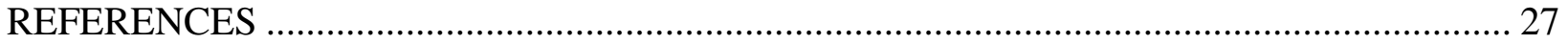

APPENDIX A: NUMERICAL VS EXPERIMENTAL TRACER STUDY ............................. 31

APPENDIX B: TRACER SAMPLING RATE ANALYSIS ............................................... 33

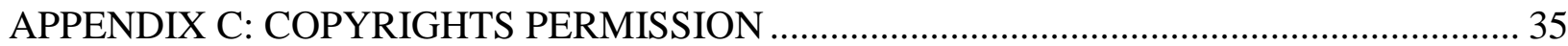




\section{LIST OF TABLES}

Table 1 Water volumes, sludge volumes and water surface elevations for Cases I-IV, IIIA

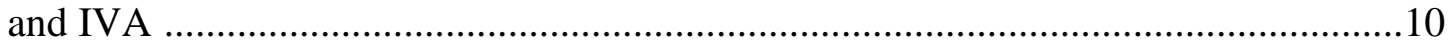

Table 2 Comparison of treatment efficiency indices and residence times for Cases I-IV ...........21

Table 3 Comparison of short-circuiting indices in Cases III, IV, IIIA and IVA ......................23 


\section{LIST OF FIGURES}

Figure 1 (A) Pond in 2006 with no sludge ........................................................................

Figure 2 Comparison of the sludge profiles on $\mathrm{x}-\mathrm{z}$ plane at mid-span of the pond for cases I-IV .10

Figure 3 Grid convergence study for Case II

Figure 4 Water flow speed contours for Cases I-IV on x-y (horizontal) planes at depth $=0 \mathrm{~m}$ (corresponding to the water surface) and depth $=0.69 \mathrm{~m}$ below the water surface (at the depth of the inlet).

Figure 5 Streamlines superimposed with flow speed contours for different sludge accumulation scenarios viewed from above the pond (top view) for Case I (panel A), Case II (B), Case III (C) and Case IV (D)

Figure 6 Snapshots of normalized tracer transport on the x-y (horizontal) at different times $(\mathrm{t}=0.5,2.0$, and 4.0 days $)$

Figure 7 Comparison of residence time distribution (RTD) curves for Cases I-IV.

Figure A1 Comparison of tracer concentration versus time from field experiment and computational fluid dynamics model simulation.

Figure B1 Tracer sampling rate analysis using CFD. 


\begin{abstract}
Improving the hydraulic performance of waste stabilization ponds (WSPs) is an important management strategy to not only ensure protection of public health and the environment, but also to maximize the potential reuse of valuable resources found in the treated effluent. To reuse effluent from WSPs, a better understanding of the factors that impact the hydraulic performance of the system is needed. One major factor determining the hydraulic performance of a WSP is sludge accumulation, which alters the volume of the pond.

In this study, computational fluid dynamics (CFD) analysis was applied to investigate the impact of sludge layer geometry on hydraulic performance of a facultative pond, typically used in many small communities throughout the developing world. Four waste stabilization pond cases with different sludge volumes and distributions were investigated.

Results indicate that sludge distribution and volume have a significant impact on wastewater treatment efficiency and capacity. Although treatment capacity is reduced with accumulation of sludge, the latter may induce a baffling effect which causes the flow to behave closer to that of plug flow reactor and thus increase treatment efficiency. In addition to sludge accumulation and distribution, the impact of water surface level is also investigated through two additional cases. Findings show that an increase in water level while keeping a constant flow rate can result in a significant decrease in the hydraulic performance by reducing the sludge baffling effect, suggesting a careful monitoring of sludge accumulation and water surface level in WSP systems.
\end{abstract}




\section{CHAPTER 1: INTRODUCTION ${ }^{1}$}

Wastewater stabilization ponds (WSPs) are a widely used and economically viable wastewater treatment technology (Mara, 2004) that are critical for sanitation provision throughout the world. Importantly this technology may be more sustainable than mechanized methods of wastewater treatment (Muga \& Mihelcic, 2008) and can be readily integrated with agricultural water reuse to improve food security, especially for smaller cities facing increasing population and urbanization (Verbyla et al.., 2013a). In addition, such an approach can offset the negative impacts of eutrophication while recovering valuable nutrients required for crop growth (Cornejo et al.., 2013).

However, there are challenges in managing a WSP associated with parasite, bacteria, and virus removal (e.g., Verbyla et al., 2013b; Verbyla \& Mihelcic, 2015). The level of pathogen removal is highly dependent on the hydraulic performance of a WSP (Verbyla \& Mihelcic, 2015), which also affects water quality parameters associated with suspended solids (SS) and biochemical oxygen demand (BOD) (Lloyd et al., 2003; Nelson et al., 2004; Verbyla et al., 2013a). Therefore, improving the hydraulic performance of a WSP is an important management strategy for not only ensuring protection of public health and the environment, but also in maximizing the potential to reuse the treated effluent.

\footnotetext{
${ }^{1}$ Portions of this chapter have been accepted for publication in Water Research, Volume 99, 1 August 2016, Pages 253-262 (Ouedraogo et al., 2016), and have been reproduced with permission from Elsevier B.V.
} 
Various mathematical models have attempted to analyze and optimize wastewater treatment systems. Early studies on hydraulic performance of WSPs mainly employed reduced order models, such as the completely mixed flow reactor (Ferrara \& Harleman, 1981; Mayo, 1995), ponds-in-series models (Canale et al., 1993), and dispersion models (Polprasert \& Bhattarai, 1985). However these models are unable to capture flow structures, such as dead zones and short-circuiting, resulting in less than optimal accuracy in predicting residence time distribution and hydraulic performance. The rapid advance of computer technology has allowed computational fluid dynamics (CFD) to be applied to wastewater treatment. CFD models have been successfully applied for analysis and optimization of the hydraulics of WSPs in previous studies (Wood et al., 1995; Wood et al., 1998; Peterson et al., 2000; Salter et al., 2000; Shilton, 2000; Vega et al., 2003; Karteris et al., 2005; Sweeney et al., 2005; Verbyla et al., 2013b). Nonetheless, predictions of CFD models on full-scale pond systems may be inaccurate due to limited consideration of the physical conditions encountered in the field.

Although sludge accumulation is crucial to long-term maintenance of WSPs (Oakley et al., 2012), only a few studies have incorporated sludge accumulation into CFD analysis (Murphy, 2012; Alvarado et al., 2012). Murphy (2012) and Alvarado et al. (2012) found that sludge distribution or geometry influences hydraulic performance. For example, the hydraulic performance in a wastewater stabilization pond when sludge is mostly deposited near the edges (e.g. Murphy, 2012) differs from the hydraulic performance when an equal volume of sludge accumulates mainly near the inlet or inflow (e.g. Alvarado et al., 2012).

Murphy (2012) also demonstrated that sludge surface roughness affects hydraulic efficiency of a pond by changing dispersion. Alvarado et al. (2012) found that sludge accumulation patterns and velocity profiles are interrelated and directly affect pond hydraulic 
performance. However, in-depth quantification of how advective transport and associated flow patterns such as short-circuiting and dead zones are affected by sludge accumulation and alter the WSP hydraulic performance is needed. In a WSP integrated with downstream beneficial reuse of water and embedded nutrients, the pond effluent is allowed to enter an irrigation system.

Changes in the operation of the system may cause a water surface level increase in the pond, which can also affect the hydraulic performance (Mercado et al., 2013). Physical understanding and quantification of the effect of water surface level on the hydraulics is needed.

Accordingly, the objective of this study is to investigate, for the first time, the impact of different sludge volume and accumulation patterns in conjunction with changes in water surface elevation on the advective transport and the hydraulic performance of a WSP. Normally, in a WSP, changes in water surface elevation are accompanied by changes in flow rate. However, in the present study, CFD simulations with various water surface elevations were performed with a fixed flow rate in order to isolate (highlight) the effect of the former on hydraulic performance.

A community managed wastewater stabilization pond in rural Bolivia was selected for this study, which is representative of a WSP utilized in a developing country. Flow and tracer transport simulations were conducted for this pond using a numerical solver of the threedimensional Reynolds-averaged Navier-Stokes equations (RANS). Sludge geometry as well as pond geometry and water flow parameters obtained in the field were used to model the pond.

The RANS solver was then used to predict the hydraulic performance of the WSP under future sludge accumulation scenarios. Numerical tracer studies on the pond with measured and potential future sludge layer geometries were conducted to analyze the impact of sludge geometry on the hydraulic performance of the WSP and to establish the importance of short and long term monitoring of WSPs. 
Numerical tracer studies were also conducted with two different water surface elevations to determine the impact of the surface level change on hydraulic performance of the pond. It was found that sludge build-up in the interior of the pond away from walls towards the inflow, diverts the flow laterally essentially serving as a baffle and causing the flow to behave closer to a plug flow reactor in some of the cases studied, ultimately increasing hydraulic efficiency relative to the pond with no sludge. An increase in water surface elevation decreases the baffling effect of the sludge by allowing short-circuiting flow over the sludge.

The CFD analysis of the WSP in Bolivia offers a case study of the effects of sludge accumulation and water surface level change on pond hydraulic performance This is important because WSPs are non-ideal reactors; thus, the creation of short circuits and dead zones can have a large influence on pathogen removal (Verbyla \& Mihelcic, 2015), which is critical for performance, whether the pond is managed only for treatment or is integrated with a strategy of resource recovery and reuse.

Furthermore, WSP operators generally argue that sludge accumulation is damaging because it reduces available pond volume and thus treatment capacity, as well as hydraulic efficiency. Reduction in hydraulic efficiency would be expected given that a reduction in available pond volume can lead to a reduction of the theoretical residence time calculated as $\tau=$ volume/flow rate. The validity of this argument will be examined via the CFD analysis presented here, especially in light of the potential baffling effect induced by the sludge as described above. 


\section{CHAPTER 2: METHODOLOGY²}

\subsection{Waste Stabilization Pond Description}

The wastewater stabilization pond system of focus here was designed to serve a population of 420 people in 2006 and served 780 people in 2012. The system consists of a facultative pond followed by two maturation ponds, and is representative of a community managed WSP system commonly found in the developing world (Cornejo et al., 2013). There are no baffles designed into this system to direct pond influent or effluent. Details on sludge accumulation, water quality (e.g., pathogen, nutrient, TSS, and BOD removal), life cycle cost, and life cycle impacts (e.g., carbon footprint, embodied energy, and eutrophication potential) can be found in previous studies (Fuchs \& Mihelcic, 2011; Verbyla et al., 2013a; Cornejo et al., 2013; Symonds et al., 2014). Lizima (2012) and Verbyla et al.. (2013a,b) have performed a study of this system that included the measurement of sludge accumulation at the bottom of the pond; this information on sludge accumulation is incorporated in the model development of the present study.

\subsection{Modelling Approach}

The CFD methodology employed is based on the RANS equations and is a common and proven accurate approach for modeling flow in water and wastewater treatment (Alvarado et al., 2012; Zhang et al., 2013a, b; Zhang et al., 2013; Zhang et al., 2014a,b). In this approach, the

\footnotetext{
2 Portions of this chapter have been accepted for publication in Water Research, Volume 99, 1 August 2016, Pages 253-262 (Ouedraogo et al., 2016), and have been reproduced with permission from Elsevier B.V.
} 
mean flow is computed explicitly and the unresolved turbulence is modeled or parameterized. The RANS turbulence model used in this study is the well-known $k$ - $\varepsilon$ (k-epsilon) model equipped with standard wall functions (Wilcox, 2004). In order to analyze characteristic residence times, a passive tracer study was performed using the RANS flow solution. The turbulent Schmidt number denoting the ratio of turbulent viscosity of the flow to turbulent diffusivity of the tracer was set to 0.7, similar to other studies (Launder, 1978; Zhang et al., 2014a).

Figure 1A provides the dimensions of the WSP modeled. A fixed flow rate boundary condition was used for the inflow at the inlet (see Figure 1A). That is, the volumetric flow rate at the inlet was fixed as $66 \mathrm{~m}^{3} / \mathrm{day}$, which is an average flow rate measured in the field by Lizima (2012) and Verbyla et al.. (2013a,b). This flow rate corresponds to a theoretical residence time of 27.6 days (volume of pond/flow rate). Once the steady state RANS solution of the flow was computed, the scalar advection-diffusion transport equation for the passive tracer was solved using the flow velocity. The numerical tracer study was conducted by initially releasing a tracer with concentration $C=1(\mathrm{~g} / \mathrm{L})$ at the inlet over a 1020 -second or 17-min period which is about $0.04 \%$ of the theoretical residence time. At the outlet of the pond, the sidewalls and the bottom, the normal gradients of $C$ were set to zero indicating zero diffusive flux across these boundaries. 

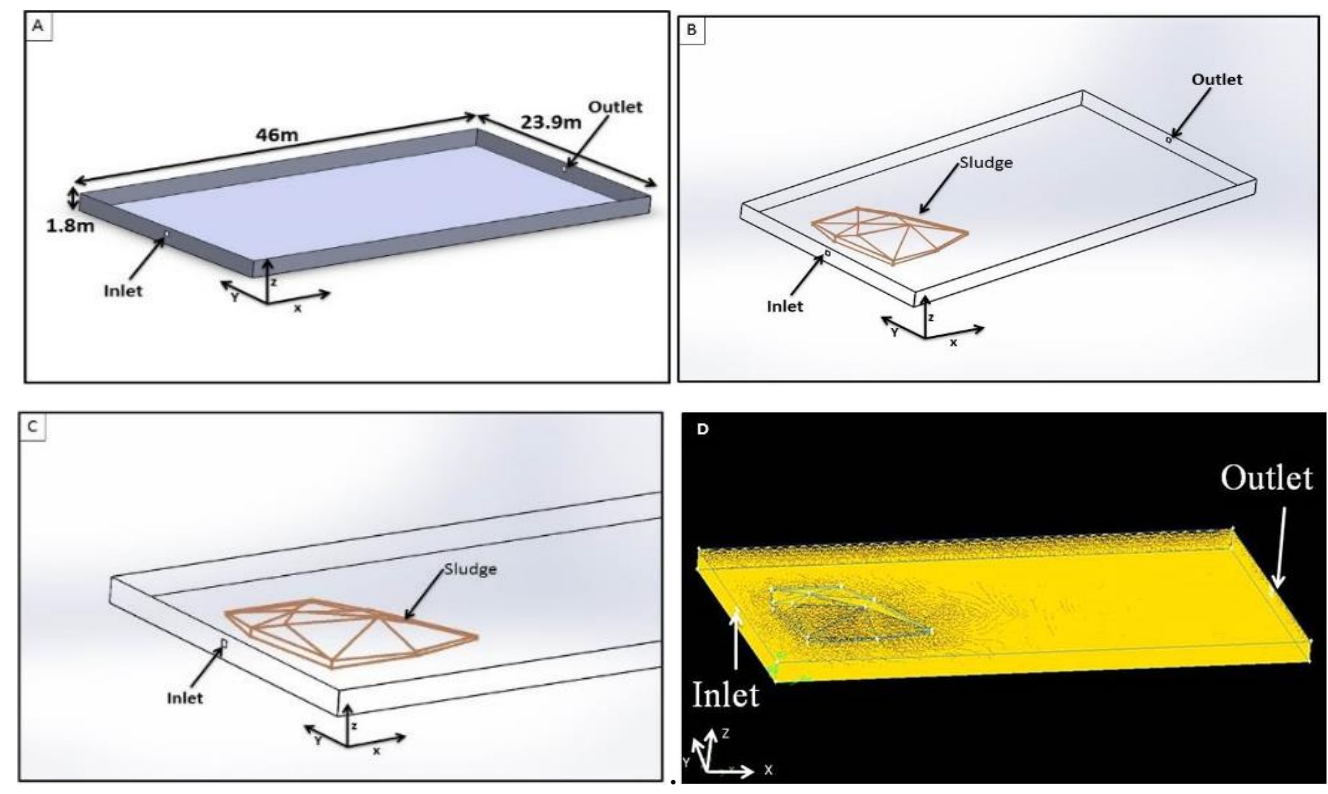

Figure 1 (A) Pond in 2006 with no sludge. Pond length is $46 \mathrm{~m}$, width is $23.9 \mathrm{~m}$ and height is $1.8 \mathrm{~m}$; the inlet and outlet cross-sectional areas are $0.25 \mathrm{~m}^{2}$ each. (B) Computational domain based on sludge profile physically measured in 2012 (Case II). (C) Close up view of inlet and sludge. (D) Corresponding computational mesh consisting of tetrahedral elements.

\subsection{Hydraulic Performance Evaluation Factors}

In analyzing results from the tracer transport simulation, the theoretical residence time, the mean residence time (MRT), the short-circuiting index $S$ (Persson, 2000), the moment index (Wahl et al., 2010), and the relative moment index (Murphy, 2012) were used. Please refer to Teixeira \& Siqueira, 2008 for further details. The short-circuiting index is defined as

$$
S=\frac{t_{16}}{\tau}
$$

where $\tau$ is the theoretical residence time and $t_{16}$ denotes the time it takes for 16 percent of the tracer injected at the inlet to exit the pond. The intensity of short-circuiting decreases with increasing value of $S$. A value of $S$ equal to 1.0 corresponds to an ideal plug flow reactor (PFR) and thus no short-circuiting occurring within the pond. Moment analysis of the normalized residence time distribution (RTD) is a tried and tested technique used to describe the distribution (Kadlec \& Knight, 1996; Werner \& Kadlec, 1996; Holland et al., 2004; Min \& Wise, 2009; cited 
in Wahl et al., 2010). Unlike the short circuiting index, the moment index is not greatly dependent on the parcel of tracer exiting the pond fastest. Rather, it is more representative of the overall shape of the RTD curve without being heavily affected by the RTD long tail, which can lead to over-prediction of the residence time (Wahl et al., 2010). The moment index is defined as

$$
\text { Moment index }=1-\int_{0}^{1}(1-\theta) F(\theta) d \theta
$$

where $F(\theta)$ is the cumulative residence time distribution function.

$$
F(\theta)=\int_{t=0}^{t=\tau} \frac{C_{t}}{C_{\text {nominal }}} \frac{1}{\tau} d t
$$

where $C_{t}$ is the tracer concentration at time $t$ and $C_{\text {nominal }}$ is the nominal tracer concentration defined as

$$
C_{\text {nominal }}=\frac{\text { tracer concentration } \times \text { tracer release time }}{\text { theoretical residence time }}
$$

The relative moment index is derived from the moment index while incorporating the decrease in water volume capacity as a result of sludge accumulation:

$$
\text { Relative Moment index }=\text { Moment index } \times \frac{\text { Volume of water }}{\text { Initial volume of water }}
$$

The moment index and the relative moment index are directly proportional to the pond hydraulic efficiency while the relative moment index also takes into account the reduction in pond volume and thus reduction in treatment capacity.

\subsection{Sludge Geometry Approach Cases}

In order to project sludge accumulation in the pond, an empirical method (Oakley, 2005) was utilized. This method predicts the annual volume of sludge $\left(V_{L}\right.$ in $\mathrm{m}^{3} /$ year $)$ as

$$
V_{L}=0.00156 \times Q_{a v} \times S S
$$

where $Q_{a v}$ is the average flow rate in $\mathrm{m}^{3} /$ day and $S S$ is suspended solids in the influent in $\mathrm{mg} / \mathrm{L}$. In the present study, the value of $S S$ measured in 2012 was $242 \mathrm{mg} / \mathrm{L}$ (Verbyla et al., 2013a) and 
was assumed to have remained constant from 2006 through 2016. The annual average flow rate $Q_{a v}$ was computed taking into account future growth in population according to the Malthus exponential model (Brauer \& Castillo-Chávez, 2011). Based on the previously described methods, the prediction for the sludge volume accumulated between 2006 (when the pond had no sludge) and 2012 given by equation eqn. (6) was $164 \mathrm{~m}^{3}$, which is approximately $6.5 \%$ higher than the physically measured data (Lizima, 2012). Thus this method is seen to lead to good predictions of future sludge accumulations.

Note that following the Mathus exponential model, the average annual flow rate increases in proportion to population over the years as was considered for the calculation of accumulated sludge volume $V_{L}$, previously described. However, for all CFD simulations performed the flow rate was taken to be constant $\left(66 \mathrm{~m}^{3} /\right.$ day $)$ in order to isolate sludge and water surface elevation effects on hydraulic performance.

Four simulation cases, described in Table 1, were developed to analyze sludge geometry effects. Case I corresponds to the WSP in 2006 when it was newly built and thus had no sludge. Case II corresponds to the WSP in 2012 with sludge volume and distribution measured by Lizima (2012). Using the sludge volume equation of Oakley (2005) (i.e. equation (6)) along with the Malthus population growth model as described earlier, the sludge volume for 2016 was estimated as $326 \mathrm{~m}^{3}$. Two different sludge layer geometries or distributions for the 2016 sludge volume (to be denoted as Cases III and IV) were considered following two assumptions: 1) the first assumption is that the increment of sludge volume from 2012 to 2016 will mostly accumulate on top of the existing sludge. The height of sludge in this scenario is assumed to increase uniformly by the same percentage everywhere (Case III); 2) the second assumption is that the incoming sludge deposits primarily in the flat area of the pond (Case IV). In this 
scenario, the peak sludge elevation is the same as in Case II and not as high as in Case III (see Figure 2). The assumed sludge accumulation geometries represent two extreme situations, where the actual sludge layer geometry should be an intermediate between these two distribution conditions. Finally note that the water surface elevation for the previously described cases (I-IV) was kept constant (see Table 1).

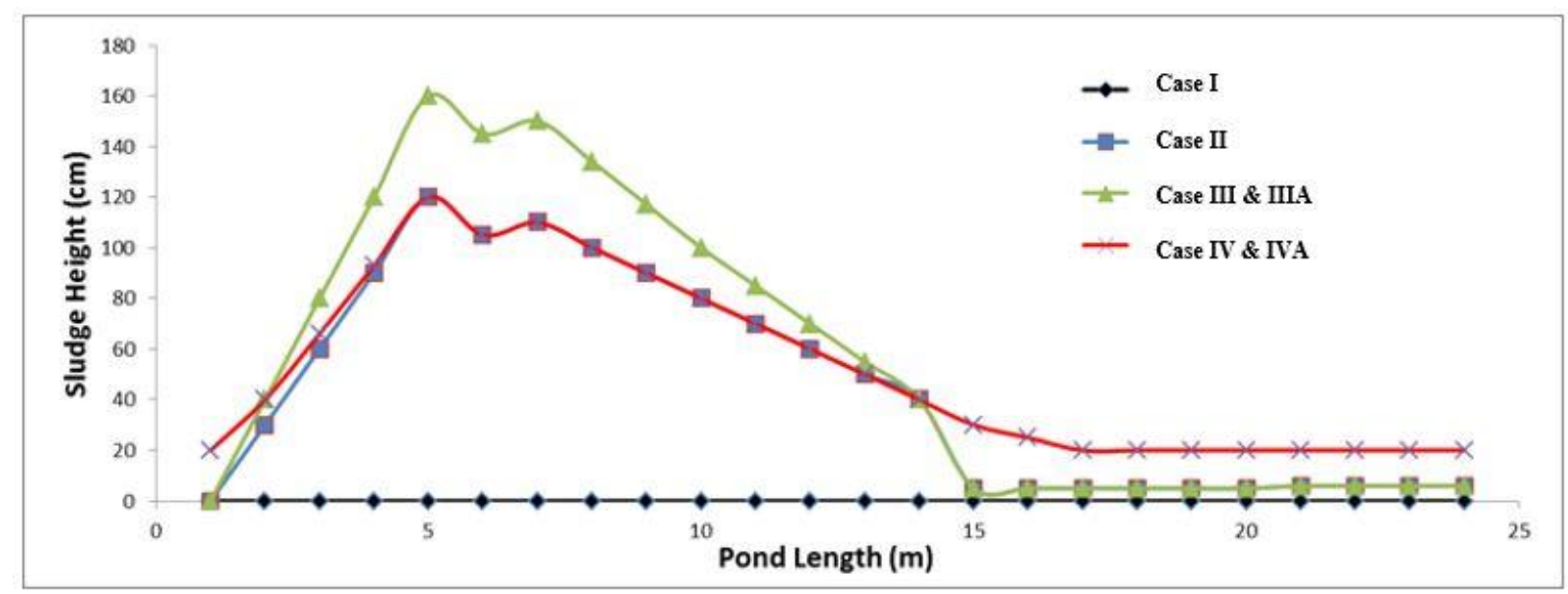

Figure 2 Comparison of the sludge profiles on $\mathrm{X}-\mathrm{z}$ plane at mid-span of the pond for cases I-IV. Case I corresponds to the WSP with no sludge (2006). Case II corresponds to the field measurements of Lizima, 2012 and Case III \& IV correspond to projected sludge accumulations in 2016.

Table 1 Water volumes, sludge volumes and water surface elevations for Cases I-IV, IIIA and IVA.

\begin{tabular}{|c|c|c|c|}
\hline Cases & $\begin{array}{c}\text { Sludge Volume } \\
\left(\mathrm{m}^{3}\right)\end{array}$ & $\begin{array}{c}\text { Water Volume } \\
\left(\mathrm{m}^{3}\right)\end{array}$ & $\begin{array}{c}\text { Water Surface Elevation } \\
(\mathrm{m})\end{array}$ \\
\hline Case I & 0 & 1979 & 1.8 \\
\hline Case II & 154 & 1815 & 1.8 \\
\hline Case III & 326 & 1643 & 1.8 \\
\hline Case IV & 326 & 1643 & 1.944 \\
\hline Case IIIA & 326 & 1815 & 1.944 \\
\hline Case IVA & 326 & 1815 & \\
\hline
\end{tabular}




\subsection{Pond Surface Water Level Approach and Cases}

In order to investigate effects of changes in water surface level, two approaches at setting the surface level for 2016 scenarios are followed. The sludge and water volumes measured in the field in 2012 by Lizima are used as reference to set the water volume and associated water surface levels. The water volume in 2012 was taken to be the total pond volume minus the sludge volume measured in the field. In one approach the water surface level for 2016 scenarios was set equal to the surface level measured in $2012(1.8 \mathrm{~m}$ from the lowest point of the bottom of the pond), corresponding to Cases III and IV in Table 1. In the second approach the water surface level for 2016 scenarios was selected to preserve the 2012 measured water volume; this corresponds to cases IIIA and IVA in Table 1. This table shows the water volumes, sludge volumes and corresponding water surface levels for all cases. Note that Cases III and IIIA have the same sludge volume and distribution and the only difference in these simulation cases is in the water surface level. The same can be stated for Cases IV and IVA.

\subsection{Mesh and Numerical Tool}

As measured by Lizima (2012) the dimensions of the computational WSP are taken as 46 $\mathrm{m} \times 23.9 \mathrm{~m} \times 1.8 \mathrm{~m}$ (length $\times$ width $\times$ depth). Water is directed into and out of the pond via 2 underground pipes (one at the inlet and another at the outlet) at a depth of $0.69 \mathrm{~m}$ below the water surface with equal and square inlet and outlet openings of $0.25 \mathrm{~m}^{2}$. The computational domain based on these dimensions along with the bottom sludge layer also measured by Lizima (2012) in 2012 is shown in Figure 1 (panels A, B and C). Based on grid independence studies (described further below), the total number of tetrahedral cells for the computational model of the previously described pond geometry was taken to be approximately 0.8 million and is shown in Figure 1C. This computational grid was refined near the walls, sludge and inlet/outlet so as to 
adequately resolve sharp gradients in velocity expected in these regions. Similar grids were used to simulate the various scenarios with different sludge geometries and water elevations described earlier. The RANS solver employed well-known finite volume discretization techniques in OpenFOAM (2011) 


\section{CHAPTER 3: RESULTS AND DISCUSSION ${ }^{3}$}

\subsection{Grid Refinement Study}

A grid refinement study is a common technique in the CFD domain for determining the dependence of results on grid size and thus on discretization (numerical) error. The present grid refinement study was comprised of four grids for the WSP for Case II from relatively fine to coarse grids: 0.8 million elements, 0.4 million elements, 0.1 million elements and 0.05 million elements. Figure 3 shows RTD of the passive tracer obtained on all 4 grids. Minor differences can be seen between results on the 0.4 and 0.8 million element grids, indicating that the 0.8 million element mesh is sufficient for nearly grid independent results.

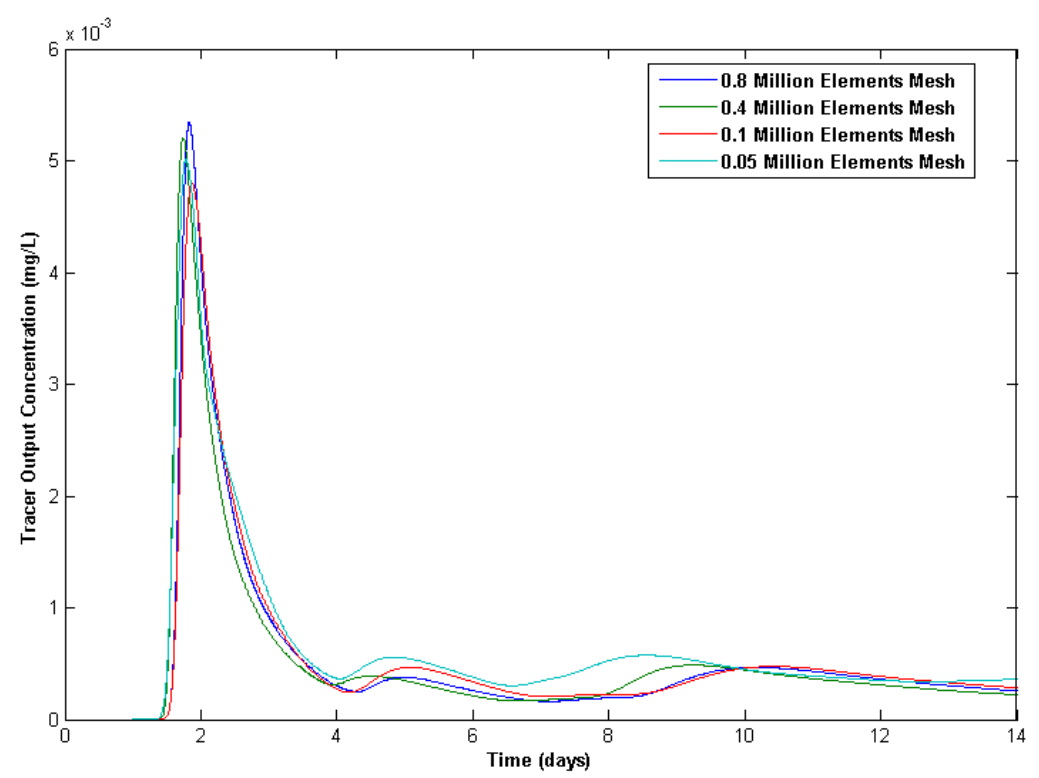

Figure 3 Grid convergence study for Case II.

${ }^{3}$ Portions of this chapter have been accepted for publication in Water Research, Volume 99, 1 August 2016, Pages 253-262 (Ouedraogo et al., 2016), and have been reproduced with permission from Elsevier B.V. 
Note that RTD data measured in the field by Lizima (2012) has been deemed undersampled for comparison with the current computations, and thus such a comparison is not presented. However, note that the CFD model used here has been validated in terms of RTD for other flow configurations (or geometries) for which fully resolved experimental RTD data is available such as flows in baffled and column contactors (Zhang et al.. (2013a) and Zhang et al.. (2014a,b)). These validation studies have shown that the present numerical model is able to predict RTDs in excellent agreement with laboratory and field measured data. In some of these cases the complex flow geometry has produced richer flow structures than in the WSP of the current study, leading to the conclusion that results for the present WSP are robust.

\subsection{Impact of Sludge Layer Geometry on Hydraulic Performance}

Next, results from flow and tracer transport simulations are presented for Cases I-IV described earlier through Table 1 and Figure 2.

Figure 4 shows water flow speed contours on $x-y$ (horizontal) planes at the water surface (A, B, C, D) and at depth of $0.69 \mathrm{~m}(\mathrm{E}, \mathrm{F}, \mathrm{G}, \mathrm{H})$ from the water surface for Cases I-IV. Note that the $0.69 \mathrm{~m}$ depth corresponds to the depth of the inlet and outlet of the pond for the four cases. At $0.69 \mathrm{~m}$ depth (Figures 4E-H), a high-speed jet can be observed originating from the inlet in all four scenarios, as expected. However, the sludge accumulation in Cases II, III and IV obstructs the path of the jet forcing it to flow laterally around the sludge and vertically over the sludge. The lateral re-direction of the jet caused by the sludge can be considered analogous to the lateral re-direction of the flow caused by baffles in a baffled reactor. As will be quantified further below via numerical tracer studies, this baffling effect caused by the sludge for certain sludge accumulation patterns, such as that in Case III, can enhance the hydraulic efficiency of the pond relative to the no-sludge scenario (Case I). 


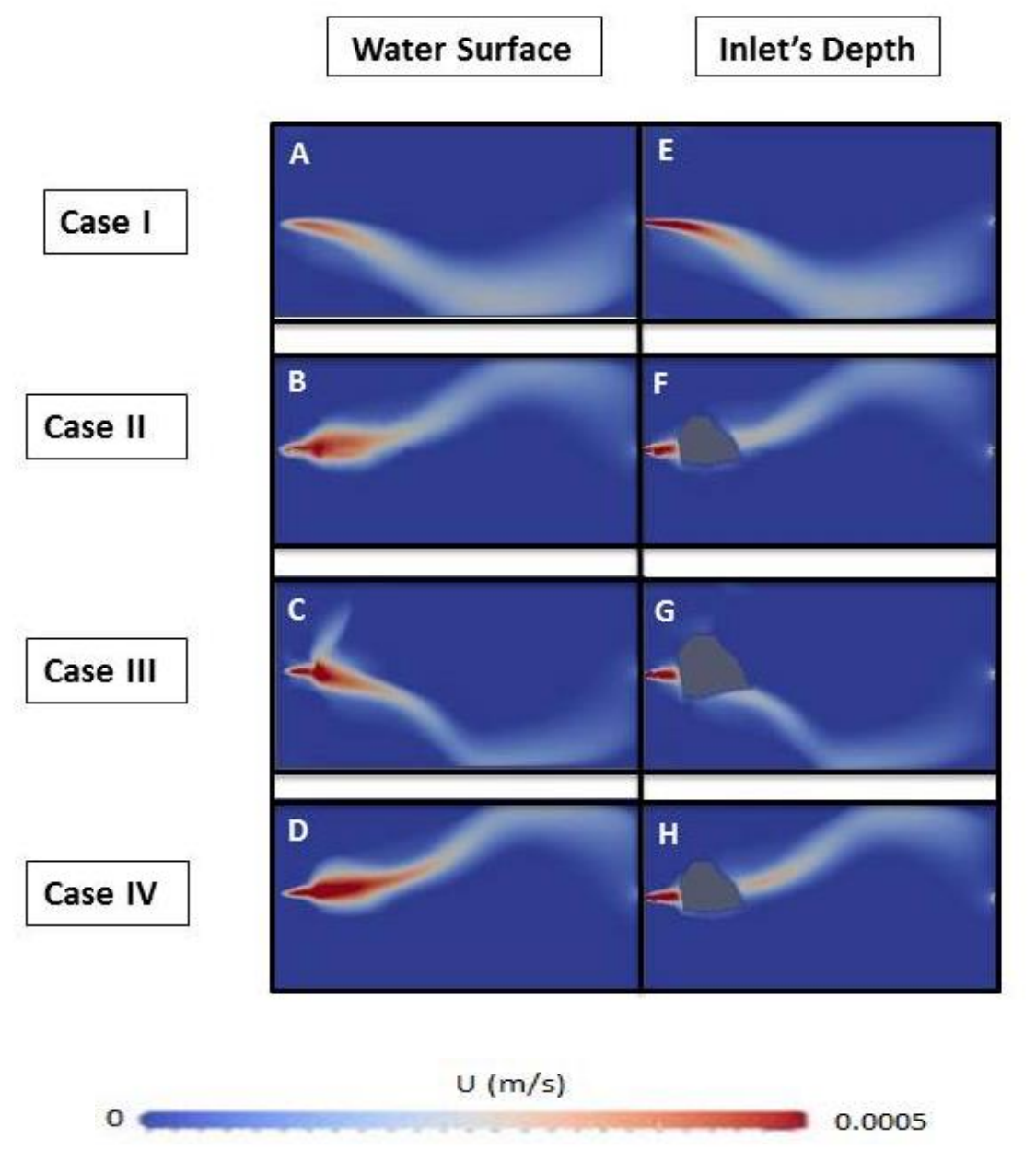

Figure 4 Water flow speed contours for Cases I-IV on x-y (horizontal) planes at depth $=0 \mathrm{~m}$ (corresponding to the water surface) and depth $=0.69 \mathrm{~m}$ below the water surface (at the depth of the inlet). The sludge accumulation is color-coded gray.

In Case III, the jet emanating from the inlet is primarily forced to change direction laterally around the sludge whereas the jet in Cases II and IV is primarily forced to change direction vertically over the sludge. The reason for this is that the sludge peak (or maximum height) in Case III reaches closer to the water surface than in the other cases extending over $90 \%$ of the total depth of the pond. This difference between the jet paths caused by the various sludge scenarios can be seen at depth $=0.69 \mathrm{~m}$ by comparing Figures $4 \mathrm{~F}, 4 \mathrm{G}$ and $4 \mathrm{H}$. Here it can be seen that flow speeds are greater around the sludge in Case III, indicative of the jet bending around this obstacle. In Cases II and IV, rather than bending around the sludge, the jet travels 
over the sludge and out of view from the plane at $0.69 \mathrm{~m}$ depth shown in Figs. 4F and 4H. After the jet goes over the sludge it goes back down and into view of the $0.69 \mathrm{~m}$ depth plane as also seen in Figs. 4F and 4H. As a result, in Cases II and IV, the flow is not seen to be as intensified around the sludge at this depth compared to Case III. It may be concluded that the baffling effect induced by the sludge is greater in Case III compared to Cases II and IV. A greater baffling effect in Case III is expected to give rise to greater hydraulic efficiency, as will be shown further below in terms of tracer studies and associated residence time characteristics.

Although the jets in Cases II-IV are obstructed by the sludge, they still travel for a certain distance at a relatively high speed compared to the jet in Case I for which no sludge layer is present. Similar high-speed jet flows can be observed in all four cases at the water surface (Figures 4A-D). The high-speed jet flow in all cases establishes a highway from inlet to outlet resulting in what is often referred to as short-circuiting. This so-called highway or short-circuit may be observed in terms of flow streamlines in Figure 5. The high-speed jet can transport particles, such as dye tracer, suspended solids and pathogens, much faster than the flow in other parts of the pond, serving as a detriment to the hydraulic efficiency of the pond.

Comparing Figures 4A and B, it can be observed that the surface jet flow in Case II (Figure 4B) is more intense than that in Case I (Figure 4A). The accumulated sludge in Case II effectively reduces the cross-sectional area through which the near-surface flow travels, ultimately enhancing the surface jet relative to the no-sludge scenario (Case I) consistent with Bernoulli's principle and conservation of mass. 


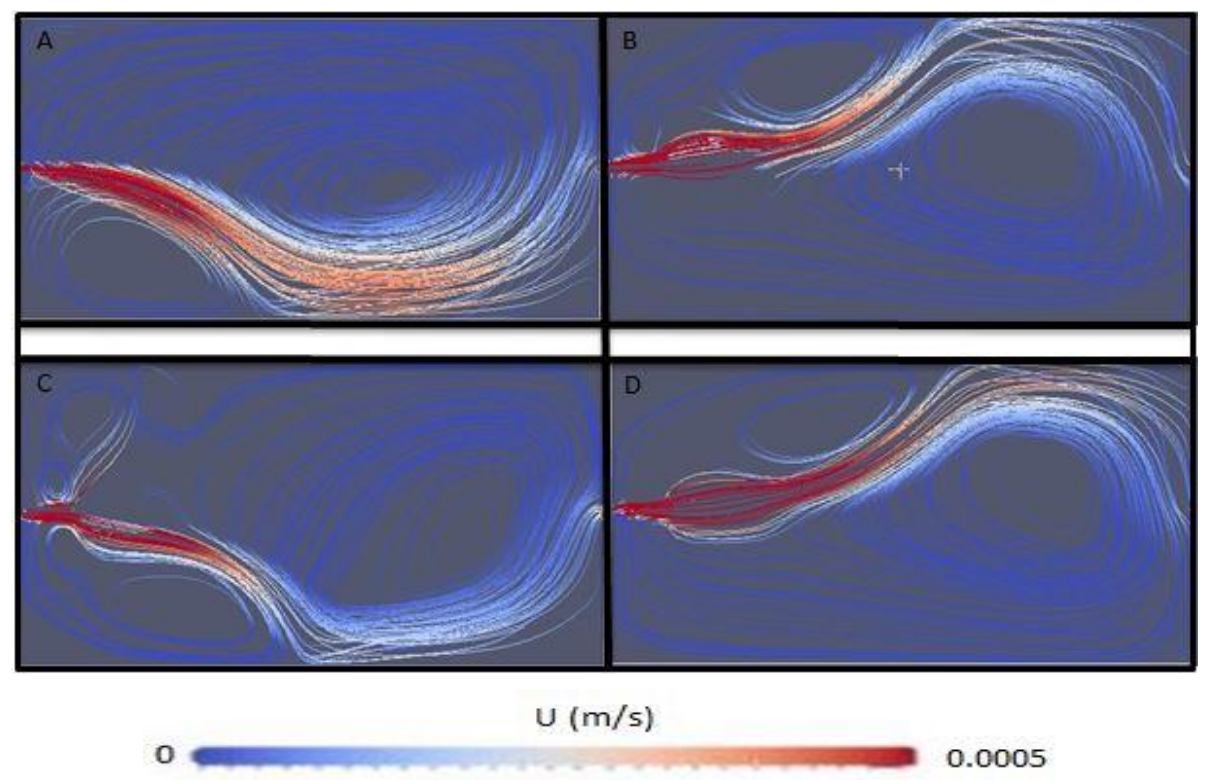

Figure 5 Streamlines superimposed with flow speed contours for different sludge accumulation scenarios viewed from above the pond (top view) for Case I (panel A), Case II (B), Case III (C) and Case IV (D).

Figures 4B, 4D, 4F and 4H demonstrate that the jet path in Case IV is similar to that in Case II. Recall that the sludge layer in Case IV has the same peak elevation as that in Case II but an overall increased sludge volume (see Figure 2). As seen through Figures 4B and 4D, the difference in the surface flow between Cases II and IV is that in the former, the jet is more damped after passing over the sludge. This suggests that the short-circuiting in Case IV is stronger than that in Case II, as will be confirmed further below. The greater short-circuiting in Case IV compared to Case II may be ultimately attributed to conservation of mass as both cases have the same flow rate with Case IV having the smaller water volume due to its greater amount of sludge.

Figure 6A-L (upper 4 rows of panels) provides snapshots of tracer concentration on the $x$ $y$ (horizontal) plane at $0.69 \mathrm{~m}$ depth at $0.5,2.0$, and 4.0 days after initial tracer release for Cases I-IV. Recall that the tracer is initially released with concentration $C=1(\mathrm{~g} / \mathrm{L})$ at the inlet for a 17-min period. At 0.5 day after initial release, the concentrated tracer patch is broken up by the 
sludge for Cases II, III and IV. At 2.0 days after the initial release, the tracer in Case IV has already reached the outlet, ahead of the tracer in Cases II and III. This is consistent with Figure 4 and the associated discussion earlier describing the greater short-circuiting at the surface in Case IV compared to Case II.

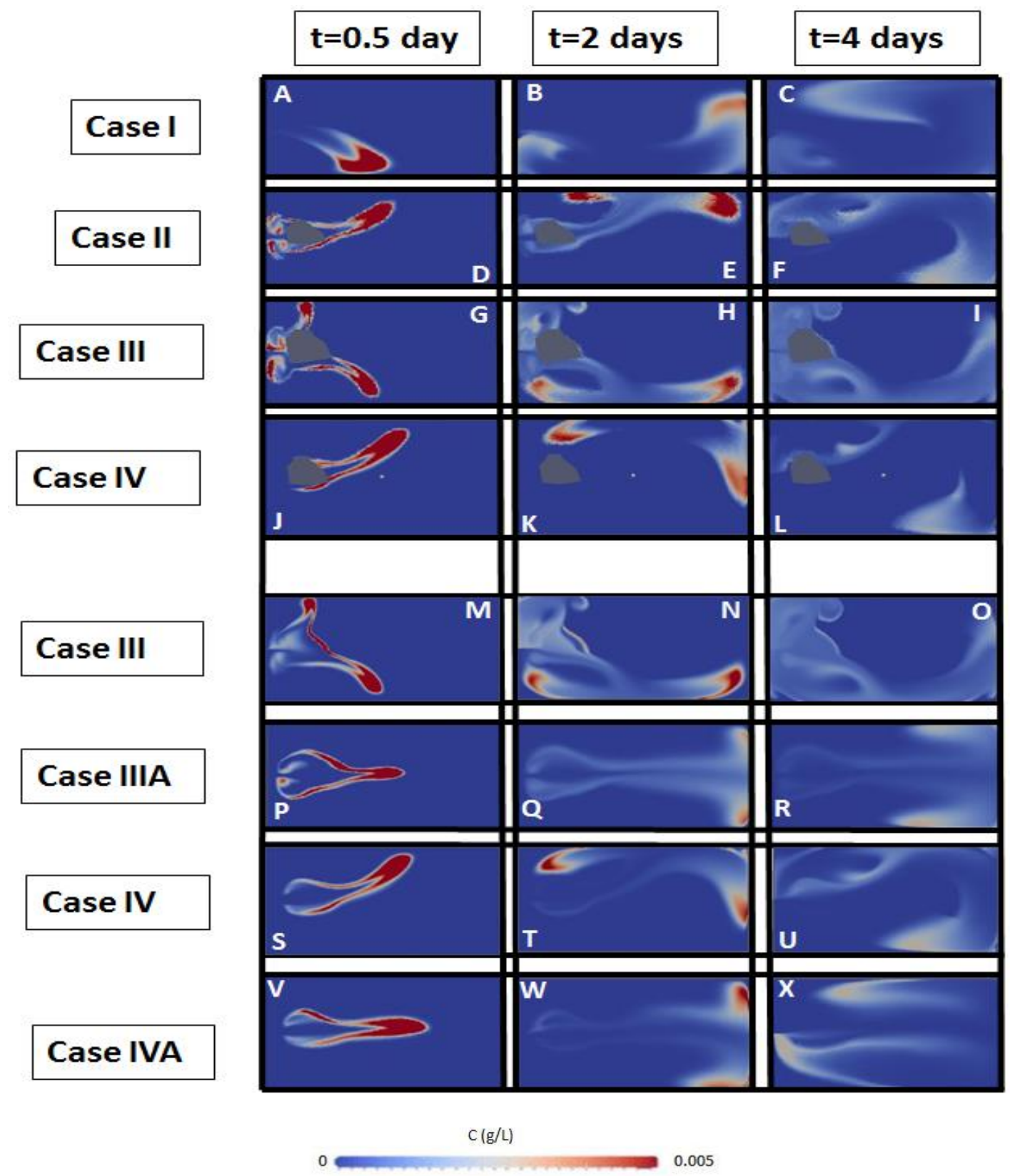

Figure 6 Snapshots of normalized tracer transport on the $\mathrm{x}-\mathrm{y}$ (horizontal) at different times $(\mathrm{t}=$ 0.5, 2.0, and 4.0 days). Panels A-L are at the depth $0.69 \mathrm{~m}$ (inlet location) the sludge accumulation is color-coded gray; and $\mathrm{M}-\mathrm{X}$ are at the water surface. 
The residence time distributions (RTDs) predicted by the simulations for Cases I-IV are compared in Figure 7. A primary peak can be found in all four curves. The time at which the primary peak occurs is mainly determined by the intensity of short-circuiting. For example, occurrence of the RTD primary peak at earlier times corresponds to more intense shortcircuiting. In Figure 7, it can be seen that Case IV possesses the strongest short-circuiting (consistent with earlier analysis), the short-circuiting in Cases I and II is almost identical and Case III has the weakest short-circuiting.

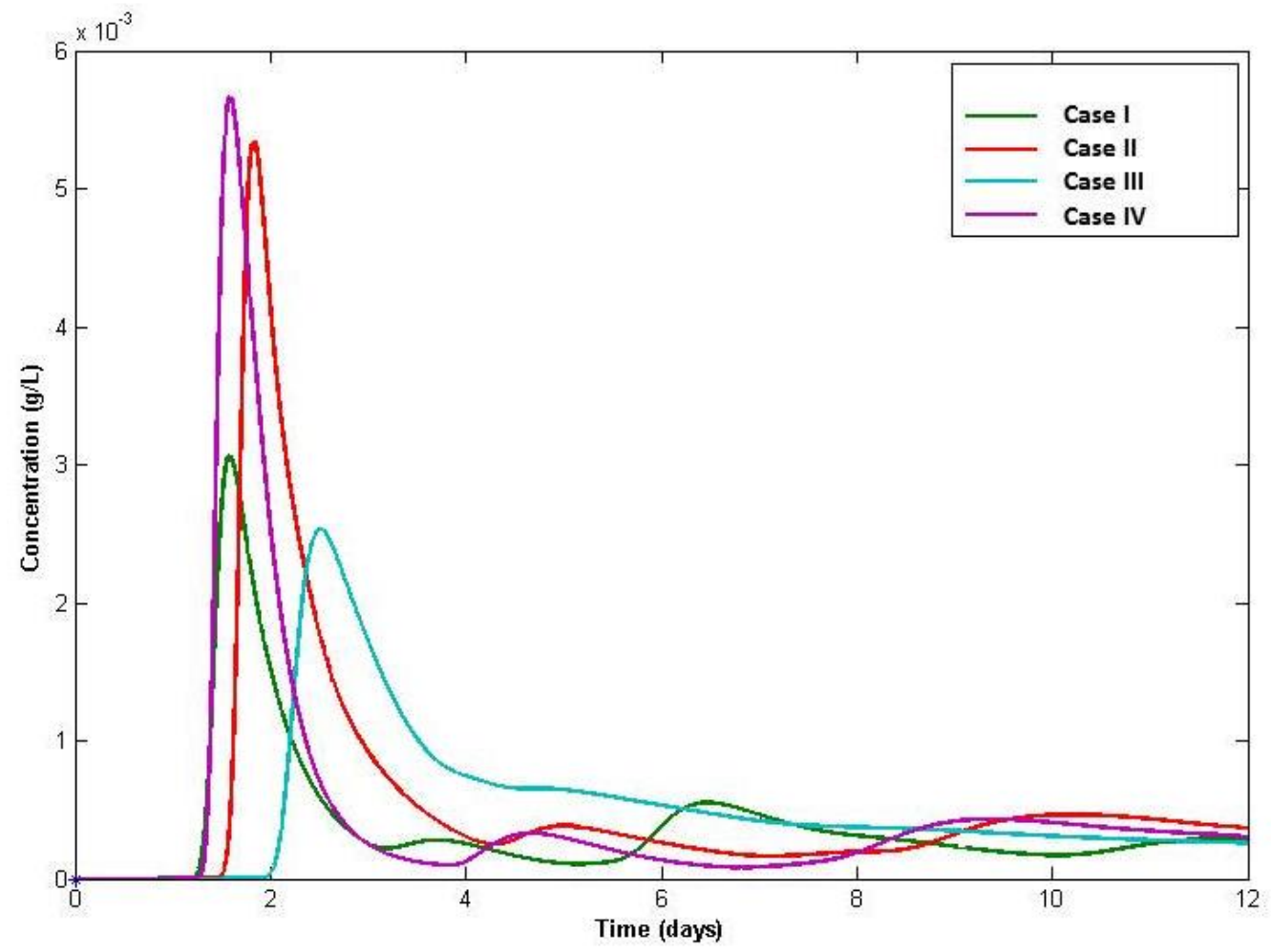

Figure 7 Comparison of residence time distribution (RTD) curves for Cases I-IV.

The short-circuiting indices $(S)$ for the four cases are calculated from Figure 7 and are listed in Table 2 . The short-circuiting index $S$ is inversely proportional to the strength of shortcircuiting and thus proportional to hydraulic efficiency. As expected from previous analysis, $S$ is 
smallest for Case IV with a value of 0.07 . Furthermore, the value of $S$ ascends going in the following order: Case IV (lowest), II, I, III (highest).

The initial pond in 2006 with no sludge (Case I) has a short-circuiting index of 0.089. Sludge accumulation by 2012 (Case II) causes the index to drop to 0.075 indicating an increase in short circuiting. In particular, this drop is attributed to the emergence of a strong jet over the sludge, as previously observed in terms of flow speed contours in Figure 4. Between 2012 (Case II) and 2016 under Case III there is sludge build up in such a way that the sludge baffling effect (described earlier) increases the short circuiting index from 0.075 to 0.118 (i.e. reducing the strength of short-circuiting). However, between 2012 (Case II) and 2016 under Case IV, the sludge build up is such that the sludge baffling effect is not enhanced as the index of Case IV is 0.07, the worst (lowest) of all 4 cases. The previous observations about Cases II, III, and IV are consistent with their mean residence times of 21.89 days, 24.86 days and 20.36 days, respectively.

Given that Cases III and IV have the same amount of sludge, it can be concluded that sludge shape (geometry) plays an important role in determining the hydraulic efficiency of the pond. Sludge deposited that reaches closer to the surface of the water creates a greater baffling effect that increases the residence time and thus the hydraulic efficiency of the pond (such as in Case III). In contrast, the same volume of sludge spread more uniformly throughout the bottom of the pond reduces hydraulic efficiency (such as in Case IV).

Although the sludge build up may seem beneficial in Case III, an increase in sludge reduces the water volume treatment capacity of the pond. This is reflected through the higher relative moment index for Case I ( 0.854$)$ compared to Case III (0.606) in Table 2. Thus, there is 
a trade-off between the gain in hydraulic efficiency and loss in water treatment capacity for Case III compared to Case I when no sludge is present.

Table 2 Comparison of treatment efficiency indices and residence times for Cases I-IV.

\begin{tabular}{|l|c|c|c|c|c|}
\hline Cases & $\boldsymbol{S}$ & $\begin{array}{c}\text { Theoretical } \\
\text { residence time } \\
\boldsymbol{\tau}\end{array}$ & $\begin{array}{c}\text { CFD-predicted } \\
\text { mean residence } \\
\text { time } \overline{\boldsymbol{\tau}}\end{array}$ & $\begin{array}{c}\text { Moment } \\
\text { Index }\end{array}$ & $\begin{array}{c}\text { Relative } \\
\text { Moment Index }\end{array}$ \\
\hline Case I & 0.089 & 29.98 & 22.93 & 0.854 & 0.854 \\
\hline Case II & 0.075 & 27.65 & 21.89 & 0.781 & 0.720 \\
\hline Case III & 0.118 & 25.04 & 24.86 & 0.7998 & 0.606 \\
\hline Case IV & 0.07 & 25.04 & 20.36 & 0.7994 & 0.606 \\
\hline
\end{tabular}

Overall, these findings have demonstrated that sludge distribution and volume have a significant impact on wastewater hydraulic efficiency. Although treatment capacity is reduced with accumulation of sludge, the latter may induce a baffling effect that can increase hydraulic efficiency. As shown by Murphy (2012), sludge roughness has an impact on hydraulic performance via dispersion. The present study demonstrates how the bulk sludge accumulation can also have an impact via advection by re-directing the flow and potentially inducing a baffling effect.

\subsection{Impact of Water Surface Level Change on Hydraulic Performance}

Results from flow and tracer transport simulations are based on the two approaches discussed earlier for setting the surface water level (see Table 1). In the first approach the water surface level for 2016 simulations (in Cases III and IV) was set equal to the water surface level of Case II corresponding to the Lizima (2012) field measurements. In the second approach, the surface water levels for 2016 simulations (in Cases IIIA and IVA) were set to maintain the same water volume measured in the field by Lizima (2012). Thus Cases III and IIIA have the same sludge distribution, but different water surface levels. The same applies for Cases IV and IVA. 
For each of these cases, three snapshots of the tracer concentration at the surface of the pond $\mathrm{t}=0.5$ day, $\mathrm{t}=2$ days and $\mathrm{t}=4$ days (after release of the tracer) are plotted in Figure $6 \mathrm{M}-\mathrm{X}$ (lower four rows of panels).

Comparing Case III with Case IIIA or IV with IVA, major differences in flow patterns at the surface and ultimately in residence times are noted due to changes in water surface elevation. For example, at time $\mathrm{t}=0.5$ day for Case IIIA (Figure $6 \mathrm{P}$ ) the tracer route is partially obstructed by the sludge. In this simulation, although the sludge still acts like a baffle as described earlier, the increase in water surface level (compared to Case III in Figure 6M-O) allows part of the tracer to flow over the top of the sludge following a more direct route to the outlet. This more direct route results in greater short-circuiting. In Case III (Figure 6M-O), the baffling effect of the sludge is greater compared to Case IIIA (Fig. 6P-R) as a greater amount of the tracer is diverted by the sludge and redirected towards the sidewalls of the pond in the former simulation. Similar conclusions can be made comparing Cases IV and IVA in Figure 6S-X. At time $t=2$ days after the release of the tracer, Cases IIIA and IVA (panels 6Q and 6W) show that a majority of the tracer has exited the pond compared to Cases III and IV (panels 6N and 6T), consistent with the greater short-circuiting induced by the higher water surface elevation in IIIA and IVA.

Short-circuiting indexes are listed in Table 3. In Case IIIA, the short-circuiting index is less than in Case III (0.066 compared with 0.118 ), thus stronger short-circuiting occurs in the former simulation, as previously concluded. Analogous results are observed when comparing Cases IV and IVA with the short-circuiting indexes of 0.07 for Case IV and 0.05 for Case IVA (higher water surface elevation). 
Table 3 Comparison of short-circuiting indices in Cases III, IV, IIIA and IVA

\begin{tabular}{|c|c|c|}
\hline Cases & Short Circuiting Index & Water Surface Level (m) \\
\hline Case III & 0.066 & 1.8 \\
\hline Case IIIA & 0.118 & 1.95 \\
\hline Case IV & 0.05 & 1.8 \\
\hline Case IVA & 0.07 & 1.95 \\
\hline
\end{tabular}

Overall, it is seen that an increase in water surface elevation can diminish the potential baffling effect induced by the sludge by opening up a path for the water to flow over the sludge. This is consistent with results from the previous sub-section showing that sludge accumulation reaching closer to the surface leads to a greater baffling effect. 


\section{CHAPTER 4: CONCLUSIONS ${ }^{4}$}

Although numerous studies in the past have performed CFD analysis of WSPs, few have analyzed the effect of sludge accumulation. Studies exist on the effect of sludge surface roughness on the dispersion and hydraulic performance of WSPs (Murphy, 2012). However, the impact of the sludge on the advective transport in the pond, that is on short-circuiting, had not been investigated until now. The present CFD study, based on physically measured and future predictions of sludge accumulation, demonstrates that an increase in sludge volume (depending on the sludge distribution or geometry) may improve the hydraulic performance of a WSP by inducing a baffling effect. For example, sludge accumulation reaching closer to the surface of the water was seen to be beneficial by preventing short-circuiting over the sludge and thus providing a greater baffling effect. This is an important benefit because many of these systems are not constructed with influent baffles. However, a tradeoff of this benefit is that sludge accumulation reduces the treatment capacity of the WSP. Furthermore, it was found that an increase in water surface elevation reduces the baffling effect of the sludge by allowing significant flow over the sludge thereby promoting short-circuiting, resulting in decrease in hydraulic efficiency.

These results demonstrate the importance of performance monitoring and the duration of such monitoring given the long-term dynamic impact of sludge accumulation coupled with water surface elevation on WSP hydraulic performance. Unfortunately rural water and sanitation

\footnotetext{
${ }^{4}$ Portions of this chapter have been accepted for publication in Water Research, Volume 99, 1 August 2016, Pages 253-262 (Ouedraogo et al., 2016), and have been reproduced with permission from Elsevier B.V.
} 
systems in the developing world have proven easier to construct than to maintain (Schweitzer \& Mihelcic, 2012).

The important interplay between sludge accumulation and water surface level determining hydraulic performance, highlighted in this study, suggests that the creation of a future CFD model capable of dynamically calculating the water surface level given a sludge distribution/amount and flow rate would be of great benefit. Dispersion caused by sludge surface roughness had been previously found to also impact hydraulic performance (Murphy, 2012); because sludge roughness is not considered in the present study, further study should be conducted to investigate the combined effect and relationship between sludge accumulation and distribution, sludge roughness, and water surface level.

This study found that the distribution of sludge in a WSP is critical for determining its hydraulic performance. A better understanding of sludge accumulation could be obtained using a more advanced CFD model, such as a liquid-solid two-phase flow model, which would dynamically couple and compute sludge distribution and water surface level. An alternative, more practical approach would be the use of single-phase CFD as in this study aided by physical measurements of sludge distribution in typical (standard) pond configurations. It is recommended that operators measure sludge accumulation and pond water surface level over long term in standard, commonly used pond configurations. Based on the data compiled, CFD may be utilized to evaluate the long-term hydraulic performance of these WSPs throughout the various stages of sludge accumulation. This information could be tabulated and provided to managers to better determine a desludging schedule that could optimize pond usage and performance. 
Finally, the results obtained here demonstrate the importance of baffling, thereby

highlighting some of the benefits that could be gained by designing and building WSPs with physical baffles. 


\section{REFERENCES}

[1] Alvarado, A., Sanchez, E., Durazno, G., Vesvikar, M., Nopens, I., 2012. CFD analysis of sludge accumulation and hydraulic performance of a waste stabilization pond. Water Science and Technology, 66:11:2370-2377.

[2] Brauer, F., \& Castillo-Chávez, C., 2011. Mathematical models in population biology and epidemiology. Springer, New York, NY, USA.

[3] Canale, R. P., Auer, M. T., Owens, E. M., Heidtke, T. M., \& Effler, S. W., 1993. Modeling fecal coliform bacteria-II. Model development and application. Water Research, 27:4:703-714.

[4] Carlston, Jeremy S.; Venayagamoorthy, Subhas Karan, 2015. Impact of Modified Inlets on Residence Times in Baffled Tanks. Journal - American Water Works Association. 107:6: E292-E300

[5] Cornejo, P. K., Zhang, Q., \& Mihelcic, J. R., 2013. Quantifying benefits of resource recovery from sanitation provision in a developing world setting. Journal of Environmental Management, 131:7-15.

[6] Ferrara, R. A., \& Harleman, D. R., 1981. Hydraulic modeling for waste stabilization ponds. Journal of the Environmental Engineering, 107:4:817-830.

[7] Fuchs, V. J., \& Mihelcic, J. R., 2011. Analyzing appropriateness in sanitation projects in the Alto Beni region of Bolivia. Waterlines, 30:122-134.

[8] Goncalves, R. F., Taveira, E. J. A., Cassini, S. T. A., \& de Oliveira, F. F., 2002. Recycled sludge thickening and digestion pond from physicochemical upgrading process of facultative pond effluent. International IWA Specialist Group Conference on Waste Stabilization in Ponds, Auckland, New Zealand.

[9] Holland, J. F., Martin, J. F., Granata, T., Bouchard, V., Quigley, M. \& Brown, L., 2004. Effects of wetland depth and flow rate on residence time distribution characteristics, Ecological Engineering, 23:3:189-203.

[10] Karteris, A., Papadopoulos, A., \& Balafoutas, G., 2005. Modeling the temperature pattern of a covered anaerobic pond with computational fluid dynamics. Water Air Soil Pollution, 162:107-125. 
[11] Lizima, L., 2013. Hydraulic Evaluation of a Community Managed Wastewater Stabilization Pond System in Bolivia. Graduate Theses and Dissertations. http://scholarcommons.usf.edu/cgi/viewcontent.cgi? article $=5556 \&$ context $=$ etd

[12] Mara, D. D., 2004. Domestic wastewater treatment in developing countries, Earthscan Publications, London.

[13] Mayo, A. W., 1995. Modeling coliform mortality in waste stabilization ponds. Journal of Environmental Engineering, 121:2:140-152.

[14] Mercado, A., Coronado O., Iriarte, M., 2013. Evaluación del funcionamiento de la planta de tratamiento de aguas residuales de Punata, Cochabamba, Bolivia. Importancia de la Operación y mantenimiento, XV Congreso Bolivariano de Ingeniería Sanitaria y Ambiental.

[15] Min, J. H. \& Wise, W. R., 2009. Simulating short-circuiting flow in a constructed wetland: the implications of bathymetry and vegetation effects, Hydrological Processes, 23:830-841.

[16] Muga, H. E. \& Mihelcic, J.R., 2008. Sustainability of Wastewater Treatment Technologies, Journal of Environmental Management, 88:437-447.

[17] Murphy, C., 2012. Quantifying the Impact of Sludge Accumulation on the Hydraulic Performance of Waste Stabilization Ponds. Bachelor's thesis, University of Western Australia.

[18] Nelson, K., Cisneros, B., Tchobanoglous, G. \& Darby, J. 2004. Sludge accumulation, characteristics, and pathogen inactivation in four primary waste stabilization ponds in central Mexico, Water Research, 38:1:111-127.

[19] Ouedraogo, F. R., Zhang, J., Cornejo, P. K., Zhang Q., Mihelcic, J. R., TejadaMartinez, A. E., 2016 Impact of sludge layer geometry on the hydraulic performance of a waste stabilization pond. Water Research, 99:253-262

[20] Oakley, S. M., 2005. Lagunas de Estabilización en Honduras: Manual de Diseño, Construcción, Operación y Mantenimiento, Monitoreo y Sostenibilidad. United States Agency for International Development-Honduras (USAID-Honduras), Red Regional de Agua y Saneamiento para Centro América (RRAS-CA), Fondo Hondureño de Inversión Social (FHIS), Tegucigalpa, Honduras.

[21] Oakley, S. M., Mendoca, L. C., \& Mendoca, S. R., 2012. Sludge removal from primary wastewater stabilization ponds with excessive accumulation: a sustainable method for developing regions. Journal of Water, Sanitation, and Hygiene for Development, 2:2:68-78. 
[22] OpenFOAM User Guide version 1.7.1, 2010. OpenCFD Ltd. 〈http://www.openfoam.com /docs/user/〉 (accessed Jul. 10, 2014)

[23] Papadopoulos, A., Papadopoulos, F., Parisopoulos, G. \& Karteris, A., 2003. Sludge accumulation pattern in an anaerobic pond under Mediterranean climatic conditions. Water Research, 37:3:634-644.

[24] Peña, M. R., Mara, D. D., \& Sanchez, A., 2000. Dispersion studies in anaerobic ponds: implications for design and operation. Water Science and Technology, 42:273-282.

[25] Perssoen, J. 2000. The hydraulic performance of ponds of various layouts. Urban Water, 2:3:243-250.

[26] Peterson, E. L., Harris, J. A., \& Wadhwa, L. C., 2000. CFD modeling pond dynamic processes. Aquacultural Engineering, 23:61-93.

[27] Polprasert, C., \& Bhattarai, K. K. 1985. Dispersion model for waste stabilization ponds. Journal of Environmental Engineering, 111:1:45-59.

[28] Schweitzer, R. W., Mihelcic, J. R., 2012. Sustainability Analysis of Community Managed Water Systems in the Developing World, Journal of Water, Sanitation and Hygiene for Development, 2:1:20-30.

[29] Shilton, A., 2000. Potential application of computational fluid dynamics to pond design. Water Science and Technology, 42:327-334.

[30] Shilton, A., Kreegher, S., \& Grigg, N., 2008. Comparison of computation fluid dynamics simulation against tracer data from a scale model and full-sized waste stabilization pond. Journal of Environmental Engineering, 134:845-850.

[31] Sweeney, D. G., Nixon, J. B., Cromar, N. J., \& Fallowfield, H. J., 2005. Profiling and modelling of thermal changes in a large waste stabilization pond. Water Science and Technology, 51:163-172.

[32] Symonds, E. M., Verbyla, M. E., Kafle, R. C., Lukasik, J. O., Breitbart, M., Mihelcic, J. R., 2014. A case study of enteric virus removal and insights into the associated risk of water reuse for two wastewater treatment pond systems in Bolivia, Water Research, 65:257-270.

[33] Teixeira, E. C., \& Siqueira, R. N., 2008. Performance Assessment of Hydraulic Efficiency Indexes. Journal of Environmental Engineering, 134:10:851-859.

[34] Verbyla, M. E., Oakley, S. M., \& Mihelcic, J. R., 2013a. Wastewater infrastructure for small cities in an urbanizing world: Integrating the protection of human health and the environment with resource recovery and food security. Environmental Science \& Technology, 47:8:3598-3605. 
[35] Verbyla, M. E., Oakley, S. M., Lizima, L. A., Zhang, J., Iriarte, M., Tejada-Martinez, A. E., \& Mihelcic, J. R., 2013b. Taenia eggs in waste stabilization pond systems with poor hydraulics: Concern for human cysticercosis? Water Science and Technology. 68:12:2698-2703.

[36] Verbyla, M. E., Mihelcic, J. R., 2015. A review of virus removal in wastewater treatment pond systems, Water Research, 71:107-124.

[37] Wahl, M. D., Brown, L. C., Soboyejo, A. O., Martin, J. \& Dong, B., 2010. Quantifying the hydraulic performance of treatment wetlands using the moment index, Ecological Engineering, 36:1691-1699.

[38] Wilcox, D. C., 1994. Turbulence Modeling for CFD. DCW Industries, Inc., La Cañada Flintridge, California.

[39] Wood, M. G., Greenfield, P. F., Howes, T., Johns, M. R., \& Keller, J., 1995. Computational fluid dynamic modeling of waste-water ponds to improve design. Water Science and Technology, 31:111-118.

[40] Wood, M. G., Howes, T., Keller, J., \& Johns, M. R., 1998. Two dimensional computational fluid dynamic models for waste stabilization ponds. Water Research, 32:958-963.

[41] Zhang, J., Tejada-Martínez, A. E., \& Zhang, Q., 2013a. RANS simulation of the flow and tracer transport in a multi-chambered ozone contactor. Journal of Environmental Engineering, 139:3:450-454.

[42] Zhang, J., Tejada-Martínez, A. E., \& Zhang, Q., 2013b. Hydraulic efficiency in RANS of the flow in multi-chambered ozone contactors, Journal of Hydraulic Engineering, 139:11:1150-1157.

[43] Zhang, J., Tejada-Martinez, A. E., Zhang, Q., \& Lei, H., 2014a. Evaluating Hydraulic and Disinfection Efficiencies of a Full-Scale Ozone Contactor using a RANS-based Modeling Framework, Water Research, 52:155-167.

[44] Zhang, J., Tejada-Martínez, A. E., \& Zhang, Q., 2014b. Evaluation of LES and RANS for Determining Hydraulic Performance of Water Disinfection Systems, Journal of Fluid Engineering, 136:12, 121102. 


\section{APPENDIX A: NUMERICAL VS EXPERIMENTAL TRACER STUDY}

The CFD model under Case II was compared with tracer concentration time series from the field measurements of Lizima (2012). As seen in Figure A.1, the primary peak of tracer concentration measured in the physical test occurred at 1.5 days after the initial tracer release while in the CFD simulation it occurred at 2 days. The tail of the curve predicted by CFD is in excellent agreement with the field data from the $3^{\text {rd }}$ through the $12^{\text {th }}$ day, the end of the physical tracer study.

The primary peak of tracer concentration predicted by CFD is higher than the field data. One possible reason of this discrepancy is that in the field experiment the primary highest peak tracer concentration actually occurred between the third and fourth sampling points (Figure A.1); if that were to be the case, then the actual peak of the tracer study would be located between 1.5 and 2 days in closer proximity to the CFD prediction. Note that the time lapse between the third and fourth sampling points in the physical experimental data in Figure A.1 is more than eight hours suggesting a higher sampling rate for future field measurements. An appropriate sampling rate is identified based on CFD prediction in Appendix B.

The readers can find the experimental tracer study data in the thesis by Lizima, 2012 at: http://scholarcommons.usf.edu/cgi/viewcontent.cgi?article=5556\&context=etd. Numerical tracer study data for the different cases in this study can be found at: www.eng.usf.edu/ aetejada/WSP. 


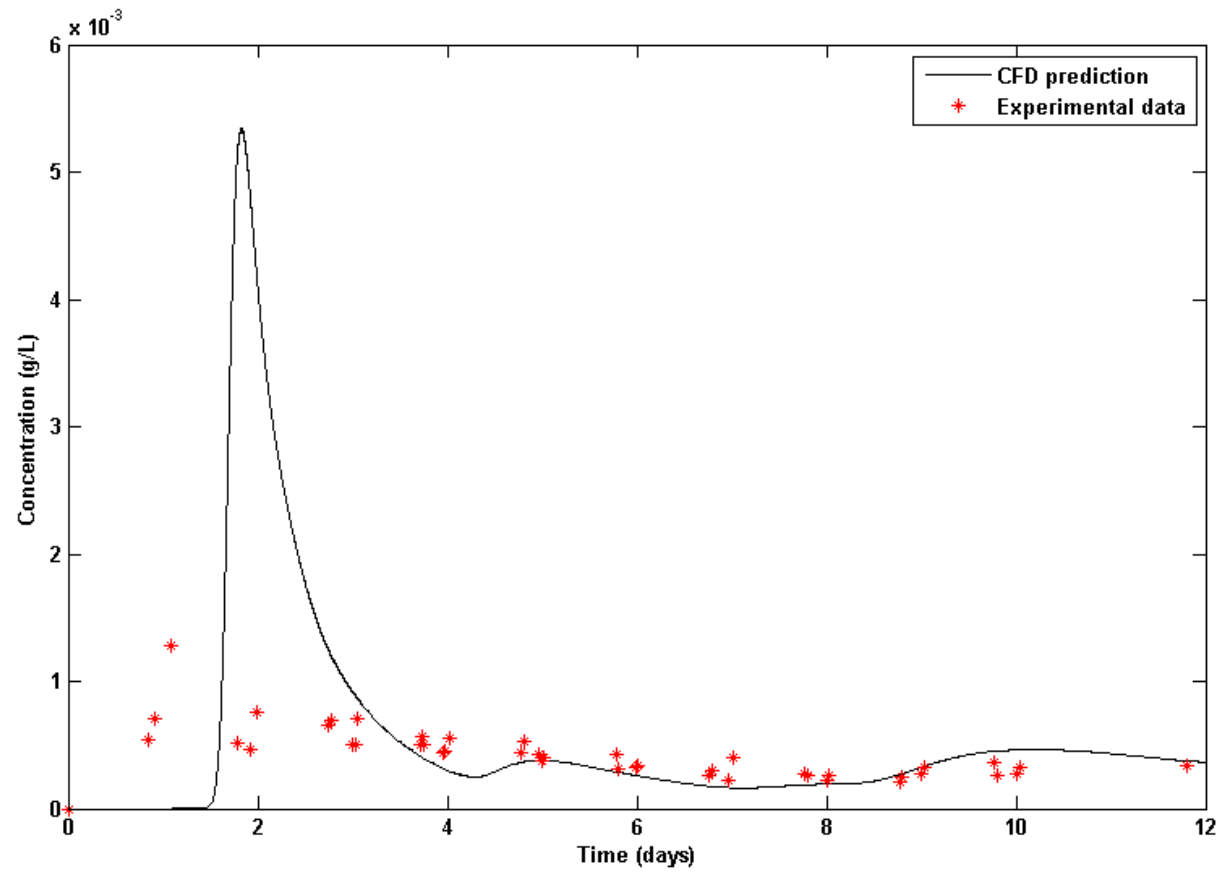

Figure A1 Comparison of tracer concentration versus time from field experiment and computational fluid dynamics model simulation. 


\section{APPENDIX B: TRACER SAMPLING RATE ANALYSIS}

Figure B1 shows a set of Residence Time Distribution (RTD) curves obtained using numerical tracer study and plotted at different time intervals corresponding to the assumed sampling rates.

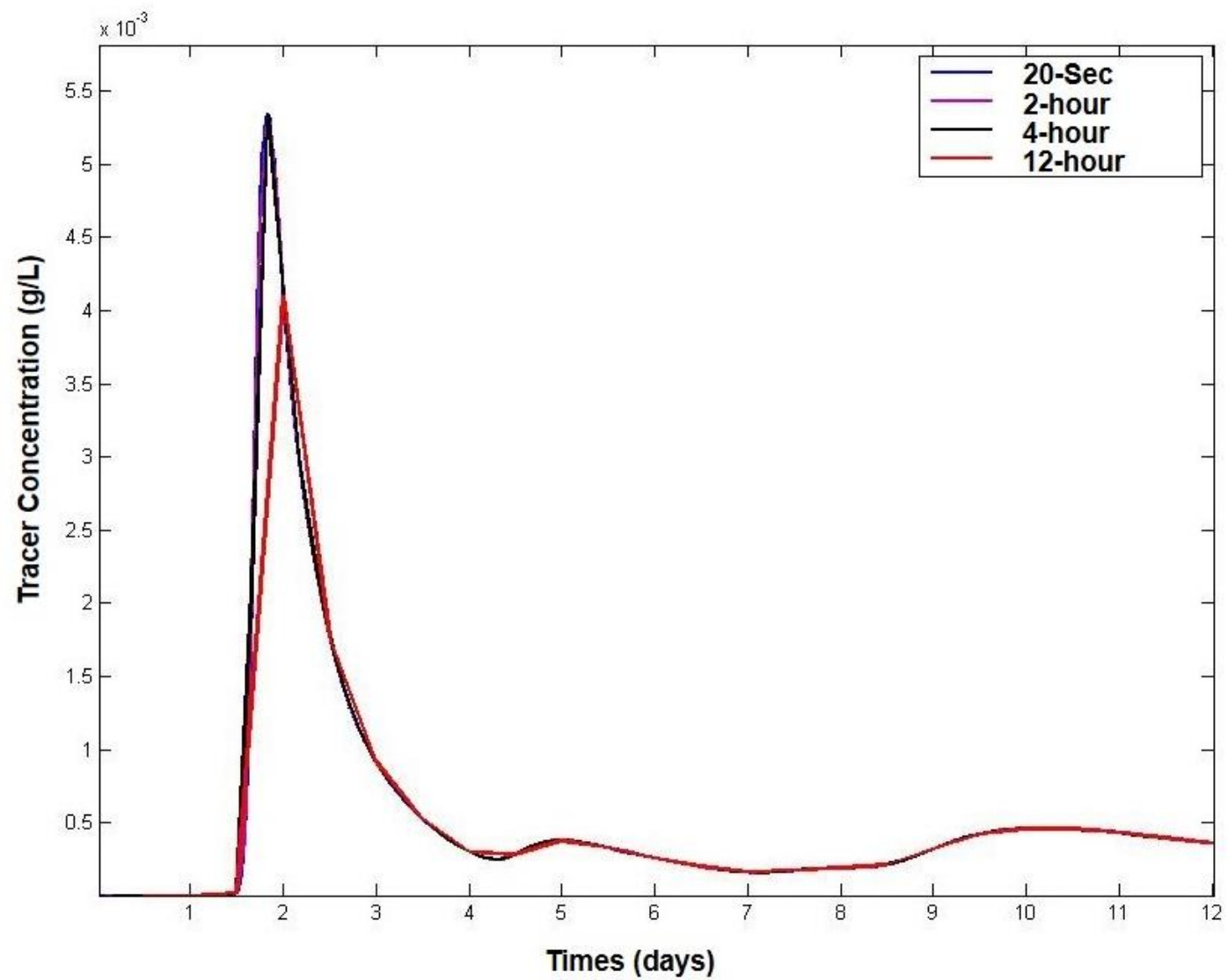

Figure B1 Tracer sampling rate analysis using CFD.

CFD has been proven to be a reliable tool in the field of waste water treatment using waste stabilization ponds (Wood et al, 1995; Wood et al, 1998; Peterson et al, 2000; Salter et al, 2000; Shilton, 2000; Vega et al, 2003; Karteris et al, 2005; Sweeney et al, 2005; Verbyla et al, 2013b). Validation of CFD models is a required step in the modelling world that checks the 
accuracy of the model's representation of the real system. This step assures that the developed model can be applied with confidence within the intended use of the model to produce satisfactory results. The most reliable and direct way of validating a model is a direct comparison of the model results to the experimental field results. In this study, the direct comparison of the numerical tracer study to the field tracer study was not feasible due to under-sampling in the field tracer study described in Appendix A. In order to avoid under-sampling in potential future field campaigns in the pond investigated here, we recommend that field tracer study be conducted with a reduced sampling time interval (i.e. 4 hours) compared to the 8-12 hour interval used previously (Lizima, 2012). Figure B1 shows comparison of numerical tracer outputs at different time intervals (20-sec, 2 hours, 4hours, and 12 hours). For time intervals less than 4 hours we notice that the RTDs are practically identical. When the time intervals are increased to 12 hours, the tail of the RTD curve agrees with that obtained finer time intervals (20-sec, 2-hr, and 4-hr) but the first peek of tracer occurs about half a day later and the tracer concentration is about $25 \%$ lower. To avoid experimental tracer studies afflicted by such errors, a sampling interval of 4 hours is suggested, at least for the first 3-4 days to adequately capture the earlier wave of tracer exiting at the outlet. This interval can be increased later after the first days since RTD curve tails are not rapidly changing. 


\section{APPENDIX C: COPYRIGHTS PERMISSION}

Below is the permission for the use of Material in Chapter 1, Chapter 2, Chapter 3, and Chapter 4.

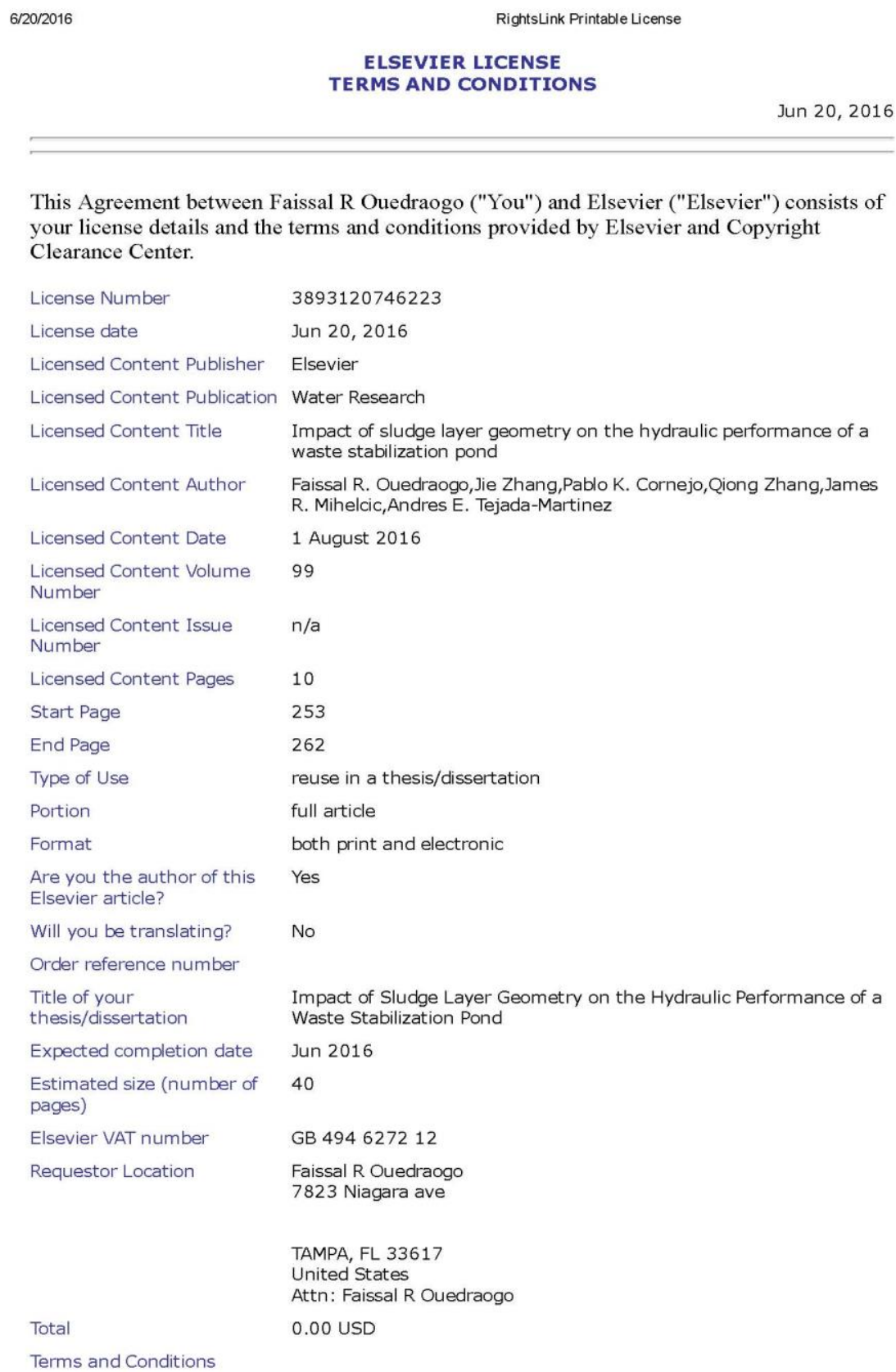




\section{INTRODUCTION}

1. The publisher for this copyrighted material is Elsevier. By clicking "accept" in connection with completing this licensing transaction, you agree that the following terms and conditions apply to this transaction (along with the Billing and Payment terms and conditions established by Copyright Clearance Center, Inc. ("CCC"), at the time that you opened your Rightslink account and that are available at any time at http:(/mvaccount.copvright.com).

\section{GENERAL TERMS}

2. Elsevier hereby grants you permission to reproduce the aforementioned material subject to the terms and conditions indicated.

3. Acknowledgement: If any part of the material to be used (for example, figures) has appeared in our publication with credit or acknowledgement to another source, permission must also be sought from that source. If such permission is not obtained then that material may not be included in your publication/copies. Suitable acknowledgement to the source must be made, either as a footnote or in a reference list at the end of your publication, as follows:

"Reprinted from Publication title, Vol /edition number, Author(s), Title of article / title of chapter, Pages No., Copyright (Year), with permission from Elsevier [OR APPLICABLE SOCIETY COPYRIGHT OWNER]." Also Lancet special credit - "Reprinted from The Lancet, Vol. number, Author(s), Title of article, Pages No., Copyright (Year), with permission from Elsevier."

4. Reproduction of this material is confined to the purpose and/or media for which permission is hereby given.

5. Altering/Modifying Material: Not Permitted. However figures and illustrations may be altered/adapted minimally to serve your work. Any other abbreviations, additions, deletions and/or any other alterations shall be made only with prior written authorization of Elsevier Ltd. (Please contact Elsevier at permissions@elsevier.com)

6. If the permission fee for the requested use of our material is waived in this instance, please be advised that your future requests for Elsevier materials may attract a fee. 7. Reservation of Rights: Publisher reserves all rights not specifically granted in the combination of (i) the license details provided by you and accepted in the course of this licensing transaction, (ii) these terms and conditions and (iii) CCC's Billing and Payment terms and conditions.

8. License Contingent Upon Payment: While you may exercise the rights licensed immediately upon issuance of the license at the end of the licensing process for the transaction, provided that you have disclosed complete and accurate details of your proposed use, no license is finally effective unless and until full payment is received from you (either by publisher or by $\mathrm{CCC}$ ) as provided in CCC's Billing and Payment terms and conditions. If full payment is not received on a timely basis, then any license preliminarily granted shall be deemed automatically revoked and shall be void as if never granted. Further, in the event that you breach any of these terms and conditions or any of CCC's Billing and Payment terms and conditions, the license is automatically revoked and shall be void as if never granted. Use of materials as described in a revoked license, as well as any use of the materials beyond the scope of an unrevoked license, may constitute copyright infringement and publisher reserves the right to take any and all action to protect its copyright in the materials.

9. Warranties: Publisher makes no representations or warranties with respect to the licensed material.

10. Indemnity: You hereby indemnify and agree to hold harmless publisher and $\mathrm{CCC}$, and their respective officers, directors, employees and agents, from and against any and all claims arising out of your use of the licensed material other than as specifically authorized pursuant to this license.

11. No Transfer of License: This license is personal to you and may not be sublicensed, assigned, or transferred by you to any other person without publisher's written permission.

12. No Amendment Except in Writing: This license may not be amended except in a writing 
signed by both parties (or, in the case of publisher, by CCC on publisher's behalf). 13. Objection to Contrary Terms: Publisher hereby objects to any terms contained in any purchase order, acknowledgment, check endorsement or other writing prepared by you, which terms are inconsistent with these terms and conditions or CCC's Billing and Payment terms and conditions. These terms and conditions, together with CCC's Billing and Payment terms and conditions (which are incorporated herein), comprise the entire agreement between you and publisher (and CCC) concerning this licensing transaction. In the event of any conflict between your obligations established by these terms and conditions and those established by CCC's Billing and Payment terms and conditions, these terms and conditions shall control.

14. Revocation: Elsevier or Copyright Clearance Center may deny the permissions described in this License at their sole discretion, for any reason or no reason, with a full refund payable to you. Notice of such denial will be made using the contact information provided by you. Failure to receive such notice will not alter or invalidate the denial. In no event will Elsevier or Copyright Clearance Center be responsible or liable for any costs, expenses or damage incurred by you as a result of a denial of your permission request, other than a refund of the amount(s) paid by you to Elsevier and/or Copyright Clearance Center for denied permissions.

\section{LIMITED LICENSE}

The following terms and conditions apply only to specific license types:

15. Translation: This permission is granted for non-exclusive world English rights only unless your license was granted for translation rights. If you licensed translation rights you may only translate this content into the languages you requested. A professional translator must perform all translations and reproduce the content word for word preserving the integrity of the article.

16. Posting licensed content on any Website: The following terms and conditions apply as follows: Licensing material from an Elsevier journal: All content posted to the web site must maintain the copyright information line on the bottom of each image; A hyper-text must be included to the Homepage of the journal from which you are licensing at http://www.sciencedirect.com/science/journal/xxxxx or the Elsevier homepage for books at http://www.elsevier.com; Central Storage: This license does not include permission for a scanned version of the material to be stored in a central repository such as that provided by Heron/XanEdu.

Licensing material from an Elsevier book: A hyper-text link must be included to the Elsevier homepage at http://www.elsevier.com . All content posted to the web site must maintain the copyright information line on the bottom of each image.

Posting licensed content on Electronic reserve: In addition to the above the following clauses are applicable: The web site must be password-protected and made available only to bona fide students registered on a relevant course. This permission is granted for 1 year only. You may obtain a new license for future website posting.

17. For journal authors: the following clauses are applicable in addition to the above: Preprints:

A preprint is an author's own write-up of research results and analysis, it has not been peerreviewed, nor has it had any other value added to it by a publisher (such as formatting, copyright, technical enhancement etc.).

Authors can share their preprints anywhere at any time. Preprints should not be added to or enhanced in any way in order to appear more like, or to substitute for, the final versions of articles however authors can update their preprints on arXiv or RePEc with their Accepted Author Manuscript (see below).

If accepted for publication, we encourage authors to link from the preprint to their formal publication via its DOI. Millions of researchers have access to the formal publications on ScienceDirect, and so links will help users to find, access, cite and use the best available version. Please note that Cell Press, The Lancet and some society-owned have different 
submitted to your institution in either print or electronic form. Should your thesis be published commercially, please reapply for permission. These requirements include permission for the Library and Archives of Canada to supply single copies, on demand, of the complete thesis and include permission for Proquest/UMI to supply single copies, on demand, of the complete thesis. Should your thesis be published commercially, please reapply for permission. Theses and dissertations which contain embedded PJAs as part of the formal submission can be posted publicly by the awarding institution with DOI links back to the formal publications on ScienceDirect.

\section{Elsevier Open Access Terms and Conditions}

You can publish open access with Elsevier in hundreds of open access journals or in nearly 2000 established subscription journals that support open access publishing. Permitted third party re-use of these open access articles is defined by the author's choice of Creative Commons user license. See our open access license policy for more information.

Terms \& Conditions applicable to all Open Access articles published with Elsevier: Any reuse of the article must not represent the author as endorsing the adaptation of the article nor should the article be modified in such a way as to damage the author's honour or reputation. If any changes have been made, such changes must be clearly indicated. The author(s) must be appropriately credited and we ask that you include the end user license and a DOI link to the formal publication on ScienceDirect.

If any part of the material to be used (for example, figures) has appeared in our publication with credit or acknowledgement to another source it is the responsibility of the user to ensure their reuse complies with the terms and conditions determined by the rights holder. Additional Terms \& Conditions applicable to each Creative Commons user license: CC BY: The CC-BY license allows users to copy, to create extracts, abstracts and new works from the Article, to alter and revise the Article and to make commercial use of the Article (including reuse and/or resale of the Article by commercial entities), provided the user gives appropriate credit (with a link to the formal publication through the relevant DOI), provides a link to the license, indicates if changes were made and the licensor is not represented as endorsing the use made of the work. The full details of the license are available at http://creativecommons.org/licenses/by/4.0.

CC BY NC SA: The CC BY-NC-SA license allows users to copy, to create extracts, abstracts and new works from the Article, to alter and revise the Article, provided this is not done for commercial purposes, and that the user gives appropriate credit (with a link to the formal publication through the relevant DOI), provides a link to the license, indicates if changes were made and the licensor is not represented as endorsing the use made of the work. Further, any new works must be made available on the same conditions. The full details of the license are available at http://creativecommons.org/licenses/by-nc-sa/4.0.

CC BY NC ND: The CC BY-NC-ND license allows users to copy and distribute the Article, provided this is not done for commercial purposes and further does not permit distribution of the Article if it is changed or edited in any way, and provided the user gives appropriate credit (with a link to the formal publication through the relevant DOI), provides a link to the license, and that the licensor is not represented as endorsing the use made of the work. The full details of the license are available at http://creativecommons.org/licenses/by-nc-nd/4.0. Any commercial reuse of Open Access articles published with a CC BY NC SA or CC BY NC ND license requires permission from Elsevier and will be subject to a fee.

Commercial reuse includes:

- Associating advertising with the full text of the Article

- Charging fees for document delivery or access

- Article aggregation

- Systematic distribution via e-mail lists or share buttons

Posting or linking by commercial companies for use by customers of those companies. 
preprint policies. Information on these policies is available on the journal homepage. Accepted Author Manuscripts: An accepted author manuscript is the manuscript of an article that has been accepted for publication and which typically includes authorincorporated changes suggested during submission, peer review and editor-author communications.

Authors can share their accepted author manuscript:

- immediately

- via their non-commercial person homepage or blog

- by updating a preprint in arXiv or RePEc with the accepted manuscript

- via their research institute or institutional repository for internal institutional uses or as part of an invitation-only research collaboration work-group

- directly by providing copies to their students or to research collaborators for their personal use

- for private scholarly sharing as part of an invitation-only work group on commercial sites with which Elsevier has an agreement

- after the embargo period

- via non-commercial hosting platforms such as their institutional repository

- via commercial sites with which Elsevier has an agreement

In all cases accepted manuscripts should:

- link to the formal publication via its DOI

- bear a CC-BY-NC-ND license - this is easy to do

- if aggregated with other manuscripts, for example in a repository or other site, be shared in alignment with our hosting policy not be added to or enhanced in any way to appear more like, or to substitute for, the published journal article.

Published journal article (JPA): A published journal article (PJA) is the definitive final record of published research that appears or will appear in the journal and embodies all value-adding publishing activities including peer review co-ordination, copy-editing, formatting, (if relevant) pagination and online enrichment.

Policies for sharing publishing journal articles differ for subscription and gold open access articles:

Subscription Articles: If you are an author, please share a link to your article rather than the full-text. Millions of researchers have access to the formal publications on ScienceDirect, and so links will help your users to find, access, cite, and use the best available version. Theses and dissertations which contain embedded PJAs as part of the formal submission can be posted publicly by the awarding institution with DOI links back to the formal publications on ScienceDirect.

If you are affiliated with a library that subscribes to ScienceDirect you have additional private sharing rights for others' research accessed under that agreement. This includes use for classroom teaching and internal training at the institution (including use in course packs and courseware programs), and inclusion of the article for grant funding purposes.

Gold Open Access Articles: May be shared according to the author-selected end-user license and should contain a CrossMark loge, the end user license, and a DOI link to the formal publication on ScienceDirect.

Please refer to Elsevier's posting policy for further information.

18. For book authors the following clauses are applicable in addition to the above:

Authors are permitted to place a brief summary of their work online only. You are not allowed to download and post the published electronic version of your chapter, nor may you scan the printed edition to create an electronic version. Posting to a repository: Authors are permitted to post a summary of their chapter only in their institution's repository.

19. Thesis/Dissertation: If your license is for use in a thesis/dissertation your thesis may be 
20. Other Conditions:

v1.8

Questions? customercare@copyright.com or +1-855-239-3415 (toll free in the US) or +1-978-646-2777. 